\title{
TRANSFORMATION OF CHERNOZEMS UNDER THE INFLUENCE OF OAK SHELTERBELT IN AGROFORESTRY LANDSCAPE OF CENTRAL RUSSIAN UPLAND
}

DOI: http://dx.doi.org/10.18509/GBP.2020.23

UDC: 550.73:[630*26:502.521(470)

\section{Yury Chendev \\ Sergei Lukin}

Aleksandr Solovyov

Anastasia Narozhnyaya

Maria Lebedeva

Belgorod State University, Russia

\begin{abstract}
The comprehensive study of the soils of the 5-row (30 meters) wind-protective 50-yrs old oak shelterbelt, oriented from South to North, on a flat watershed agroforestry landscape was conducted (Belgorod oblast, south of Central Russian Upland). The soils are Luvic Chernozems. For 50 years the spatial differences in properties of soils under shelterbelt and on adjacent arable lands have been formed. Soils of shelterbelt content more spaces of krotovinas (tunnels of steppe animals - mole rats) comparatively with arable soils. Under forest canopy the process of textural differentiation on content and stocks of mineral particles less than $0.005 \mathrm{~mm}$ is proceeding. Arable soils adjacent to the shelterbelt contain less carbonates than soils under shelterbelt. Inside the shelterbelt the zoning was formed due to differences in the intensity of soil formation in the shelterbelt center, and at its edges: in the center the maximum intensity of clay removal, accumulation of $\mathrm{C}$ org. and hydrolyzable $\mathrm{N}$ were revealed. The maximum contents of mobile $\mathrm{P}_{2} \mathrm{O}_{5}$ are located in soils under shelterbelt edges as a result of phosphorus pumping by tree roots at adjacent arable lands.
\end{abstract}

Keywords: shelterbelts, chernozems, soil transformation.

\section{INTRODUCTION}

The practice of agroforestry in the northern Eurasia (the former territory of the Soviet Union) has a long and successful history of implementation in agricultural activities in different natural and soil zones. At the same time, not enough attention is paid to the matters of studying the role of agroforestry in increasing land productivity; moreover, the authors note a large decline in interest to this problem in the post-Soviet period of the country's development [4].

The role of shelterbelts in the transformation of morphological and other soil features remains one of the urgent problems of agroforestry development [1-9].

Study in this direction is particularly important in the area of the most fertile soils chernozems.

The aim of this study was to analyze spatial trends in properties of chernozems formed under the influence of shelterbelts in the territory of forest-steppe of the Central Russian Upland. 


\section{OBJECTS AND METHODS}

Studies of soils associated with the shelterbelt in the agroforestry landscape were carried out in the Yakovlevsky district of the Belgorod oblast (Fig. 1).

The climate of the study area is moderately continental. The average annual temperature is plus $7^{\circ} \mathrm{C}$, July temperature is plus $20^{\circ} \mathrm{C}$, January temperature is minus $6^{\circ} \mathrm{C}$. The annual precipitation is $550-600 \mathrm{~mm}$.

A

B

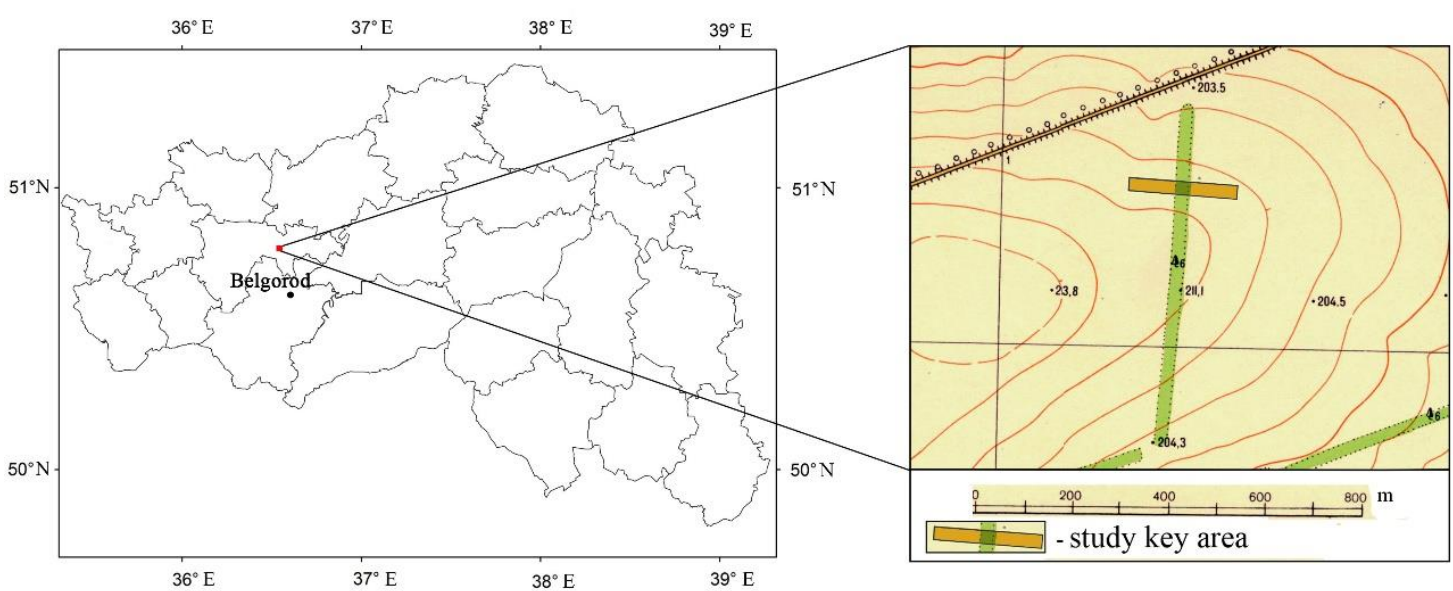

Figure 1. Location of the key research area in the South of the

Central Russian Upland (Belgorod oblast) (A) and the study area plan on a large scale (B)

For the study, the protective shelterbelt was selected, bordering on two sides with arable lands and oriented from south to north to achieve its equal exposure effect on adjacent soils. The shelterbelt is located on the flat watershed with the absolute height of 208-209 meters. The shelterbelt is a 5-row oak stand with a width of 30 meters; the age of the shelterbelt is estimated at 50 years. To determine the age of the shelterbelt, tree annual rings were counted in tree cores extracted with Haglof drill.

The shelterbelt was planted on the previously plowed area. This is indicated by the signs of the soils under the shelterbelt, specifically the remains of the old-arable horizon with increased bulk density at the depth of $20-40 \mathrm{~cm}$ and the deterioration of the aggregate state in this layer.

The specialization of farms in the fields near the shelterbelt is focused on the cultivation of fallow row-crops and grain crops.

The studied area is represented by light-clay leached chernozems (Luvic Chernozems), formed on carbonate heavy loess-like loams with a content of physical clay (fraction less than $0.01 \mathrm{~mm}$ ) in the range of $50-60 \%$ of the parent materials mineral mass.

The main methods of field soil study were the morphological analysis of soil profile, method of sketching the front walls of soil profiles displaying inclusions of the tunnels of burrowing animals - mole rats, the method for the soil sampling along three equidistant (at a distance of 10 meters) transects, and also the comparative research method.

The following types of analyses were conducted in the laboratory. The soil bulk density was determined via soil sampling with steel rings of fixed volume in triplicate in arable soil horizons and in soil profiles at different depths. Particle-size distribution was determined by the pipette method with sodium pyrophosphate pretreatment according to State Standart (GOST) 12536. The carbon of carbonates was determined by the manometric method $1 \mathrm{~h}$ after the beginning of the reaction of the soil samples with $10 \%$ 
$\mathrm{HCl}$ added in excess to the vessels with rubber stoppers. The organic carbon content was determined by Tyurin's (wet combustion) method according to GOST 26213-91. Hydrolyzable nitrogen was determined in accordance with GOST P 53219-2008. Determination of mobile compounds of phosphorus $\left(\mathrm{P}_{2} \mathrm{O}_{5}\right)$ by Chiricov method was executed according to GOST 26204-91.

\section{RESULTS AND DISCUSSION}

Under the shelterbelt the bulk density in the entire soil profile is significantly reduced up to the depth of 180-200 cm (Fig. 2A). Among the reasons of this phenomenon, we should point out the activity of soil animals, as well as the likely loosening effect of tree roots that extend to the depth of more than 2.5 meters (tree roots were found in samples taken from the deep cores of bore-wells). When analyzing the degree of over digging of the soil by mole rats, we found the higher percentage of the krotovinas area (by mole rats tunnels) of the front walls of soil sections in the soils under the shelterbelt (table. 1).
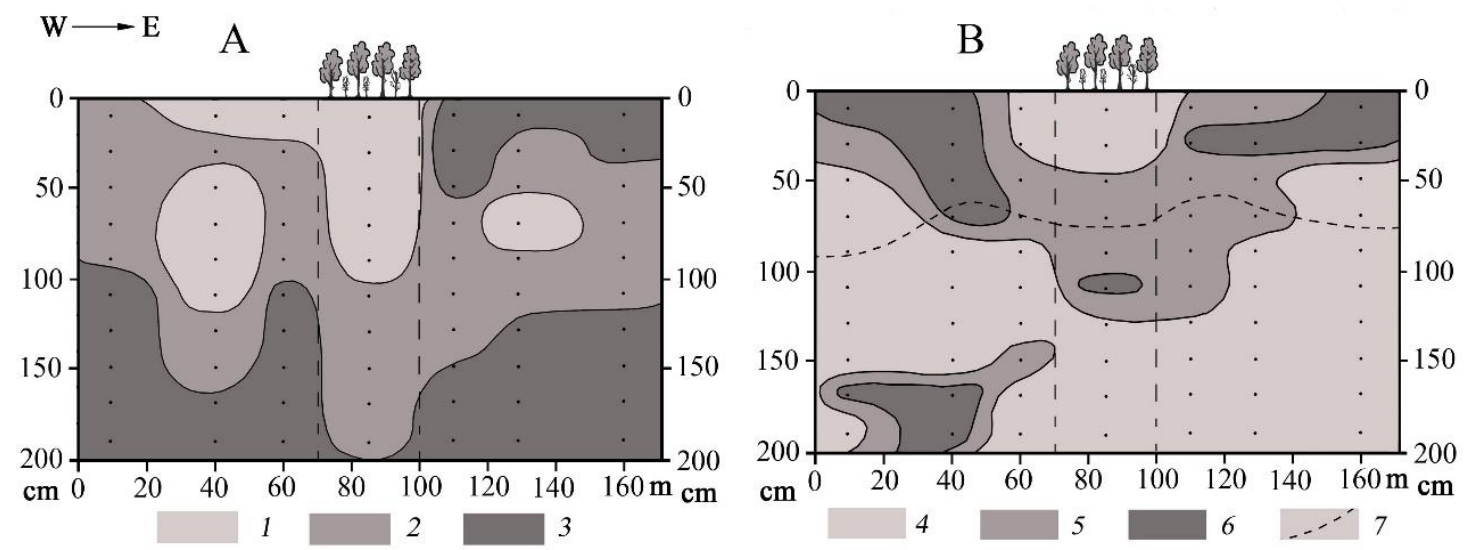

Figure 2. Distribution of soil properties under the shelterbelt and in adjacent areas of arable fields: A - bulk density, $\mathrm{g} / \mathrm{cm}^{3}$ ( 1 - less 1.2; 2 - 1.2-1.4; 3 -more than 1.4); B - the total content of clay and fine silt (particles less than $0.005 \mathrm{~mm}$ ), \% (4-less than 50; 5-50-54; 6-more than 54; the upper line of effervescence is displayed on the scheme by the symbol 7

Given that krotovinas in soil profiles persist for a long time, we can assume that immediately after the shelterbelt creation there was a period of activation of these animals in the soil space allocated for the shelterbelt. We believe that this occurred during the first years after young trees planting, when the area could still function in the mode of fallow, grass-covered land, to which the burrowing animals could migrate. Change of particlesize content in the upper layers of the soil under the shelterbelt (Fig. 2B) can be interpreted as the result of the fine-disperse granulometric fractions removal to the underlying layers as the result of lessivage - one of the most important soil-forming processes in soils under broad-leaved forests. Spatial distribution of granulometric fractions capable of lessivage i.e. particles of clay and fine silt, indicates that the topsoil with the thickness of $50-55 \mathrm{~cm}$ was depleted (contains less than $50 \%$ of the total mineral base), and the layer of 50(55)$130 \mathrm{~cm}$ - enriched with this fraction (Fig. 2B).

Specifics of the distribution of organic carbon and carbon of carbonates analyzed by the calculation of their pools in soil layers up to the depth of 3 meters (Fig. 3). Analysis of carbon stocks in the one-, two- and three-meter thicknesses of the studied soils shows that differences in organic matter are found in the upper meter of soils; they are leveled when considering organic carbon stocks in the 3-meter soil strata. In terms of carbon stocks of 
carbonates, the trend of leaching of carbonates from arable soils is obvious in comparison with the nearby soils of shelterbelt. On an arable soils layer of $0-200 \mathrm{~cm}$, loss of carbonates carbon averaged $57 \mathrm{t} / \mathrm{ha}$, and in a layer of $0-300 \mathrm{~cm}-84 \mathrm{t} / \mathrm{ha}$ (Fig. 3).

Table 1. Space of visually determined tunnels of mole rats (\% of the section area) in studied chernozems

\begin{tabular}{|c|c|c|c|c|}
\hline \multirow{2}{*}{ Layer, cm } & \multicolumn{4}{|c|}{ Soils } \\
\cline { 2 - 5 } & $\begin{array}{c}\text { under shelterbelt, } \\
\mathrm{n}=2\end{array}$ & $\begin{array}{c}\text { arable land in } \\
10 \mathrm{~m} \text { from the } \\
\text { edge, } \mathrm{n}=2\end{array}$ & $\begin{array}{c}\text { arable land } \\
\text { in 30 m from the } \\
\text { edge, } \mathrm{n}=2\end{array}$ & $\begin{array}{c}\text { arable land } \\
\text { 60 } \mathrm{m} \text { from the edge, } \\
\mathrm{n}=2\end{array}$ \\
\hline $0-40$ & 10.0 & 0.3 & 3.6 & 0.8 \\
\hline $40-80$ & 66.4 & 44.2 & 50.8 & 50.1 \\
\hline $80-120$ & 46.6 & 35.4 & 57.5 & 36.3 \\
\hline $120-160$ & 18.7 & 7.2 & 23.7 & 10.5 \\
\hline $0-160$ & 35.4 & 21.8 & 33.9 & 24.4 \\
\hline
\end{tabular}

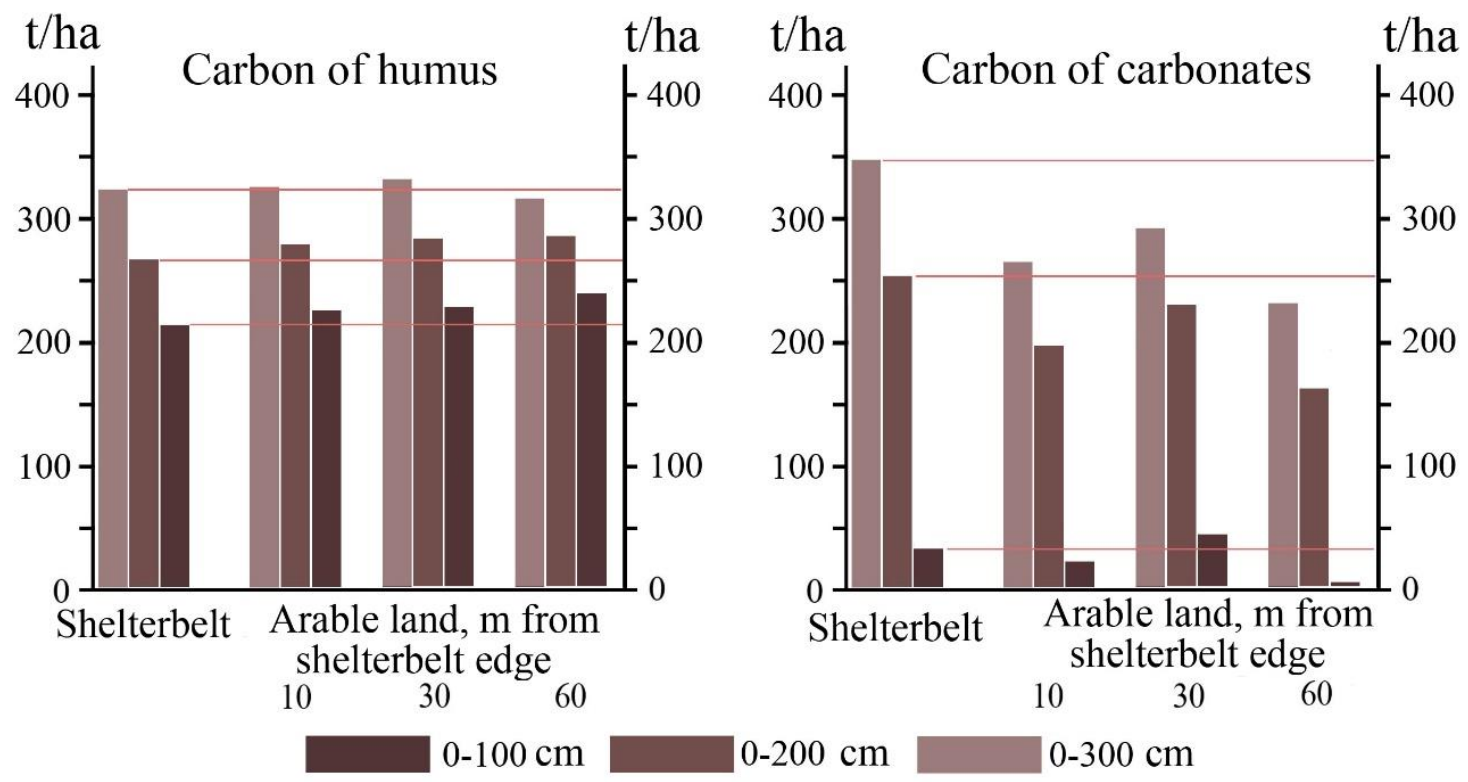

Figure 3. Stocks of humus and carbonates in the layer 0-100, 0-200 and 0-300 cm of the studied soils

Among the features that change within the soil space under the shelterbelt and on adjacent lands, the distribution of pools of thin granulometric fractions, carbon of soil organic matter and the content of hydrolyzed nitrogen are distinguished (Fig. 4). In particular, these three indicators were chosen as examples of the clearly expressed spatial differentiation of soil properties from the center of the shelterbelt to its edges. Close to symmetrical, reduction patterns (for $\mathrm{C}$ org. and nitrogen) or growth (for particles less than $0.005 \mathrm{~mm}$ ) of indicators from the center of the shelterbelt to its edges are shown in the figure 4A, C, D. These changes prove the natural character of spatial transitions of soil properties as a result of different intensity of soil-forming processes in different locations within the shelterbelt. Earlier, American researchers paid attention to such natural changes in soil properties [9].

Also noteworthy is the fact that the noticeable increase in the content of mobile phosphorus in the soils under the shelterbelt is observed not in the center, but in the edge zones of the shelterbelt - closer to its borders with arable lands (Fig. 4 B). We consider that it is the result of the «pumping» part of the phosphorus from arable land (which regularly receives mineral fertilizers) in the border areas of the shelterbelt soils. These elements can be absorbed by the tree roots of near arable lands, and then, with falling off 
leaves and branches - get into the soil. Thus, the functioning of the shelterbelts as biogeochemical barriers that accumulate matter of agricultural amelioration in the upper layer of soils in their edge parts and, in particular, phosphorus is carried out.
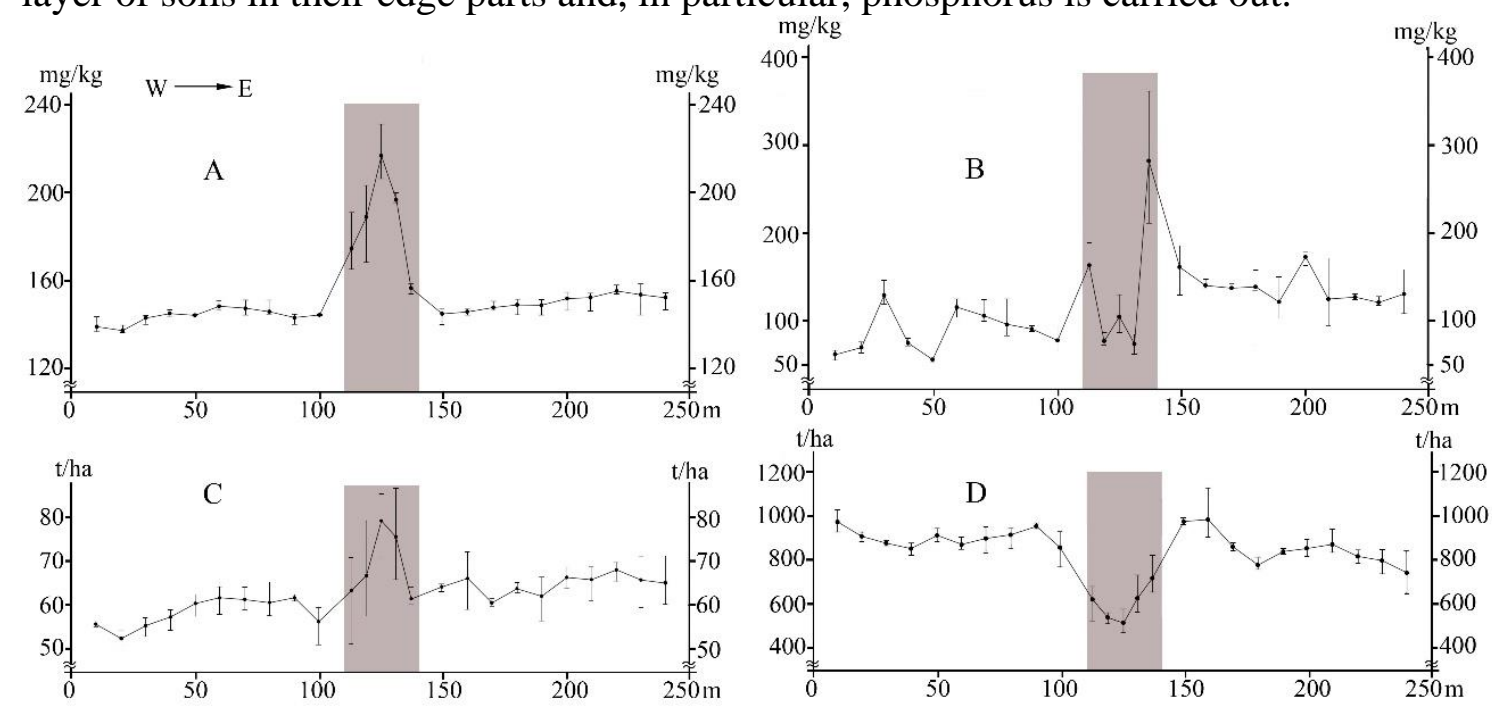

Figure 4. Average values (from triplicate for transects) in the layer of 0-20 cm of soil in arable fields adjacent to the shelterbelt and under the shelterbelt (the space under the shelterbelt is highlighted in gray):

$\mathrm{A}$ - the content of hydrolyzable nitrogen; $\mathrm{B}$ - the content of mobile phosphorus $\left(\mathrm{P}_{2} \mathrm{O}_{5}\right)$; $\mathrm{C}$ - pools of organic carbon; D - stocks of fraction $<0.005 \mathrm{~mm}$

\section{CONCLUSIONS}

Thus, the long-term growth of the oak shelterbelt had the impact on the profile features of chernozems. During the first years after planting young trees in place of the shelterbelt design, when the area was still functioning in the mode of grass-covered land, chernozem under the shelterbelt was exposed to noticeable processing by the mole rats, which was reflected in the increase of the area occupied by those animals tunnels, especially in the interval of depths of 0-80 cm In modern soils of the shelterbelt in comparison with the surrounding arable soils the bulk density to the depth of $180-200 \mathrm{~cm}$ is significantly reduced. In soils under the shelterbelt, the process of textural differentiation of the profile according to the content and stocks of particles less than $0.005 \mathrm{~mm}$ is occurred. The removal of these fractions was observed in the $0-50 \mathrm{~cm}$ layer, and their accumulation occurred in the 50-130 cm layer. Arable soils adjacent to the shelterbelt contain less carbonates than soils under the shelterbelt: in the 0-200 cm layer, the removal of carbonates in arable soils averaged $57 \mathrm{t} / \mathrm{ha}$, and in the $0-300 \mathrm{~cm}$ layer $-84 \mathrm{t} / \mathrm{ha}$.

Within the shelterbelt the zonality was formed due to the differences in specificity and intensity of soil formation processes at different areas across the shelterbelt transverse profile: in the center of the shelterbelt the maximum intensity of accumulation for hydrolyzable nitrogen and $\mathrm{C}$ org, as well as the maximum removal of fraction $<0.005 \mathrm{~mm}$ have been detected. In the edge parts of the shelterbelt in the soils the maximums of mobile phosphorus content were ascertained.

\section{Acknowledgments}

This study was supported by the grant of Russian Science Foundation, project No. 19-1700056. 


\section{REFERENCES}

[1] Agroforestry and soil fertility. Ed. By E.S. Pavlovskiy, Moscow, 288 p., 1991 (in Russian).

[2] Brandle J.R., Hodges L., and Zhou X.H. Windbreaks in North American agricultural systems, Agroforestry Systems, vol. 61, pp. 65-78, 2004.

[3] Chendev Y.G., Sauer T.J., Gennadiev A.N., et al. Accumulation of organic carbon in chernozems (Mollisols) under shelterbelts in Russia and the United States, Eurasian Soil Science, vol. 48 (1), pp. 43-53, 2015.

[4] Ierusalimskii V.I., and Rozhkov V.A. The multifunctional role of protective forest plantations, Byulleten Pochvennogo instituta im. V.V. Dokuchaeva, vol. 88, pp. 122-138, 2017 (in Russian).

[5] Kaganov V.V. Changes in ecosystem carbon stocks in the afforestation of the steppe and semidesert zones of European Russia, Regional Environmental Issues, no. 4, pp. 7-12, 2012 (in Russian).

[6] Korolev V.A., Gromovik A.I., and Ionko O.A. Changes in the physical properties of soils in the Kamennaya Steppe under the impact of shelterbelts, Eurasian Soil Science, vol 45 (3), pp. 257-265, 2012.

[7] Maryganova V., Szajdak L.W., Tychinskaya L., and Parmon S. Chemical composition and hydrophobic-hydrophilic properties of humic acids from soils under shelterbelts of different age, Physical, chemical and biological processes in soils. Ed. by L.W. Szajdak and A.K. Karabanov, Poznan': Wydawnictwo-Drukarnia „Prodruk”, pp. 359-372, 2010.

[8] Pinho R.C., Miller R.P., and Alfaia S.S. Agroforestry and the Improvement of Soil Fertility: A view from Amazonia, Applied and Environmental Soil Science, vol. 2012, 11 pp, 2012.

[9] Sauer T.J., Cambardella C.A., and Brandle R.B. Soil carbon and tree litter dynamics in a red cedar-scotch pine shelterbelt, Agroforestry Systems, vol. 71, pp. 163-174, 2007. 